\title{
Wpływ kardiowertera-defibrylatora na jakość życia - przegląd badań
}

\author{
Effect of implantable cardioverter-defibrillator on quality of life \\ - a review of research
}

\author{
Mateusz Kuśmierz ${ }^{1}$, Marta Wleklik², Izabella Uchmanowicz², Joanna Jaroch ${ }^{1}$ \\ ${ }^{1}$ Oddział Kardiologiczny Dolnośląskiego Szpitala Specjalistycznego im. T. Marciniaka Centrum Medycyny Ratunkowej we Wrocławiu \\ ${ }^{2}$ Katedra Pielęgniarstwa Klinicznego Wydziału Nauk o Zdrowiu Uniwersytetu Medycznego we Wrocławiu
}

\section{Streszczenie}

Implantacja kardiowertera-defibrylatora (ICD) w celu zmniejszenia śmiertelności u pacjentów obciążonych wysokim ryzykiem wystapienia zagrażających życiu arytmii komorowych stała się leczeniem z wyboru. Skutkuje to dynamicznie zwiększającą się liczbą chorych z ICD. W ostatnim czasie rośnie zainteresowanie jakością życia (QoL) takich pacjentów. Wnioski z badań dotyczących wpływu ICD na QoL są niejednoznaczne. Celem niniejszej publikacji jest przegląd wybranych badań dotyczących wpływu terapii za pomocą ICD na jakość życia chorych, ze szczególnym uwzględnieniem wpływu na QoL interwencji wysokoenergetycznych.

Słowa kluczowe: ICD, jakość życia, interwencje wysokoenergetyczne

Folia Cardiologica 2016; 11, 1: 28-36

\section{Wstęp}

Automatyczny kardiowerter-defibrylator (ICD, implantable cardioverter-defibrillator) po raz pierwszy wszczepiono 4 lutego 1980 roku w John Hopkins Hospital w Baltimore. Jednym z pionierów terapii za pomocą ICD był urodzony w 1924 roku w Warszawie lekarz polskiego pochodzenia Mieczysław Mirowski. W Polsce pierwszy ICD, z elektrodami nasierdziowymi, został wszczepiony przez zespół Śląskiej Akademii Medycznej w 1986 roku [1]. W 1995 roku rozpoczęto w kraju implantacje ICD z elektrodami wprowadzonymi przezżylnie. Pierwsze wszczepienie odbyło się w II Klinice Chorób Serca w Gdańsku, a następnie, w tym samym roku, w Klinice Kardiologii Śląskiej Akademii Medycznej oraz II Klinice Choroby Wieńcowej Instytutu Kardiologii w Warszawie [2].

Wyniki dużych, wieloośrodkowych, randomizowanych badań klinicznych wykazały korzyści w postaci zmniejszenia śmiertelności w grupie chorych leczonych za pomocą ICD w porównaniu z grupa chorych leczonych bez użycia tych urządzeń. Korzyści takich dowiedziono zarówno w grupie chorych, którzy przeżyli zatrzymanie krążenia spowodowane arytmiami komorowymi (prewencja wtórna nagłej śmierci sercowej [SCD, sudden cardiac death]) [3-5], jak i u chorych obciążonych zwiększonym ryzykiem wystąpienia zagrażających życiu arytmii komorowych w przyszłości (prewencja pierwotna SCD) [6-8].

Wspólne wytyczne amerykańskich towarzystw kardiologicznych, tj. American College of Cardiology (ACC) i American Heart Association (AHA), oraz Europejskiego Towarzystwa Kardiologicznego (ESC, European Society of Cardiology) [9] wraz z niskim ryzykiem zabiegu wszczepienia ICD przyczyniły się do wzrostu liczby implantowanych urządzeń.

Według danych opublikowanych przez European Heart Rhythm Association (EHRA) w 2009 roku w Polsce 
implantowano 5276 ICD, a w 2012 roku - już 7006 ICD. Skutkuje to dynamicznie się zwiększającą, niejednorodną demograficznie i klinicznie populacją pacjentów, którzy w sposób indywidualnie zróżnicowany odbierają i przeżywają swoją chorobę oraz leczenie za pomocą ICD. Oprócz zmniejszenia śmiertelności celem leczenia powinna być także poprawa jakości życia chorych (QoL, quality of life). Wyniki badań sugerują istnienie związku między obniżoną QoL a zwiększonym ryzykiem zgonu u pacjentów z komorowymi zaburzeniami rytmu serca [10].

\section{Pojęcie jakości życia zależnej od stanu zdrowia}

Jakość życia jest pojęciem wielodyscyplinarnym, w związku z czym jest różnie definiowana. Według Światowej Organizacji Zdrowia (WHO, World Health Organization) jest to „sposób postrzegania przez jednostkę jej pozycji życiowej w kontekście kulturowym oraz systemu wartości, w którym żyje, w powiązaniu do jej zadań, oczekiwań, standardów i obaw", która wpływa na wymiar fizyczny i psychologiczny życia, poczucie niezależności i relacje społeczne jednostki [11].

W naukach medycznych QoL rozpatruje się powszechnie przez pryzmat choroby i interwencji leczniczych jako jakość życia zależną od stanu zdrowia (HRQoL, health-related quality of life). Jednym z pierwszych, którzy wprowadzili pojęcie HRQoL, był w 1990 roku Schipper, który QoL zależną od stanu zdrowia określił jako „funkcjonalny efekt choroby i jej leczenia, odbierany i przeżywany przez pacjenta". Koncepcja ta wiąże się ściśle z holistycznym, biopsychospołecznym podejściem do zdrowia i choroby, w którym istotnym elementem podejmowania ingerencji medycznych staje się nie tylko fizyczne funkcjonowanie i wydłużanie życia pacjentów, ale również ich wpływ na psychikę, funkcjonowanie społeczne czy wymiar duchowy $[12,13]$.

Do oceny HRQoL najczęściej wykorzystuje się subiektywną ocenę własnego stanu zdrowia dokonywaną przez chorego na podstawie udzielanych przez niego odpowiedzi na pytania zawarte w odpowiednich kwestionariuszach [14]. Brak ujednoliconej metody oceny QoL utrudnia porównywanie wyników badań.

\section{Wpływ implantacji ICD na QoL ze szczególnym uwzględnieniem wpływu interwencji wysokoenergetycznych (przegląd wybranych badań randomizowanych i obserwacyjnych)}

Podstawowymi funkcjami ICD są szybka detekcja i przerwanie potencjalnie śmiertelnych arytmii komorowych za pomocą:

- stymulacji antytachyarytmicznej (ATP, antytachycardia pacing) (ryc. 1)

lub

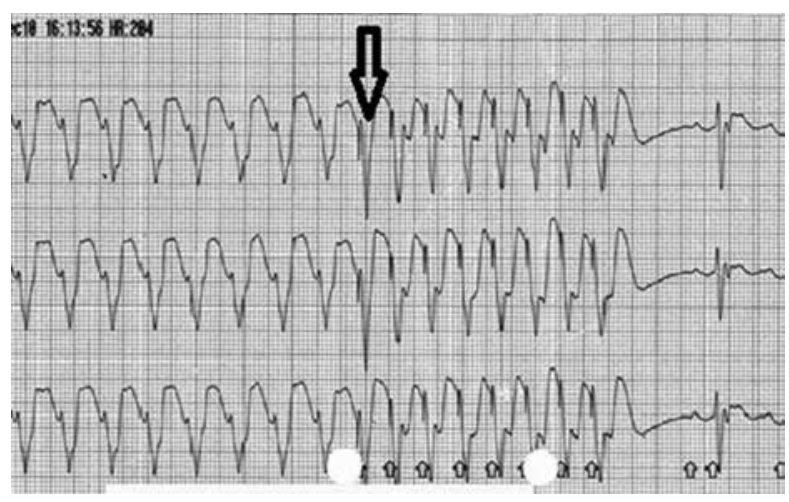

Rycina 1. Fragment zapisu elektrokardiograficznego (EKG) częstoskurczu komorowego, który zostaje przerwany stymulacją antytachyarytmiczną (ATP, antytachycardia pacing); początek terapii ATP wskazano strzałką

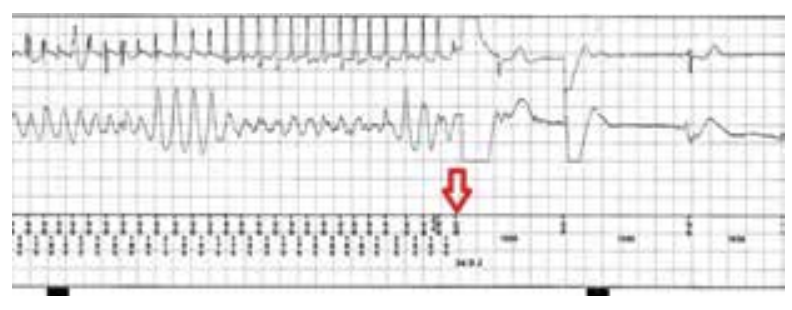

Rycina 2. Fragment zapisu z pamięci implantowanego kardiowertera-defibrylatora (ICD, implantable cardioverter-defibrillator) - wewnątrzsercowy zapis z elektrody ICD migotania komór przerwanego interwencją wysokoenergetyczna/wysokonapięciową; moment defibrylacji zaznaczono strzałką

- interwencji wysokoenergetycznej (shock lub ICD discharge) (ryc. 2).

Interwencje wysokoenergetyczne są odczuwane przez pacjentów jako nieprzyjemne bolesne uderzenia w okolicy klatki piersiowej, niejednokrotnie połączone z zaburzeniami świadomości i poczuciem zagrożenia życia. W badaniu MADIT II (Multicenter Automatic Defibrillator Implantation Trial II) w trakcie 3-letniej obserwacji interwencji wysokoenergetycznych doświadczyło około 35\% pacjentów [15], zaś w badaniu AVID (Antiarrhytmics Versus Implantable Defibrillators Trial) w trakcie 31-miesięcznej obserwacji - aż 60\% chorych [3]. Wyniki badań służących ocenie wpływu ICD na QoL pacjentów są niejednoznaczne. Wśród specyficznych dla ICD czynników ryzyka obniżenia QoL wymienia się [16, 17]:

- wiek poniżej 50. roku życia;

- częste interwencje wysokoenergetyczne;

- ograniczoną wiedzę i niezrozumienie własnej choroby oraz terapii z użyciem ICD.

Wyniki porównania QoL chorych z ICD z populacją osób z chorobami kardiologicznymi bez ICD również są niejednoznaczne. Autorzy wskazują na niższą QoL w grupie 
chorych z ICD [18] lub brak istotnych różnic pod względem QoL między obiema grupami pacjentów [19], podkreślając jednocześnie negatywny wpływ interwencji wysokoenergetycznych na ocenę QoL. Inni autorzy wykazują, że QoL pacjentów po implantacji ICD zależy głównie od innych niż ICD czynników, takich jak na przykład objawowa niewydolność serca [20].

Ocena wpływu ICD na QoL chorych była przedmiotem odrębnych analiz wielu prospektywnych, wieloośrodkowych, randomizowanych badań klinicznych, takich jak: AVID, CIDS (Canadian Implantable Defibrillator Study), CABG-Patch (Coronary Artery Bypass Graft-Patch Trial), Pain-FREE Rx II (Pacing Fast Ventricular Tachycardia Reduces Shock Therapies)czy AMIOVIRT (Amiodarone versus Implantable Defibrillator) [21-25].

\section{Badanie AVID}

Głównym celem badania AVID (1016 pacjentów; 507 ICD i 509 bez ICD) było porównanie skuteczności terapii ICD z leczeniem antyarytmicznym (AAD, antiarrhythmic drugs) u chorych, którzy przebyli epizod migotania komór lub objawowego częstoskurczu komorowego. Wykazano istotne zmniejszenie śmiertelności w grupie z ICD, co było przyczyną przedwczesnego zakończenia badania [3].

Jakość życia analizowano za pomocą kwestionariusza Short Form 36 (SF-36) po 3, 6 i 12 miesiącach u 800 chorych (416 z ICD i 384 z AAD), którzy przeżyli rok [23]. Wykazano obniżoną wyjściową QoL w obu grupach pacjentów w porównaniu z poziomem QoL ogólnej amerykańskiej populacji dorosłych. Porównując grupy chorych z ICD z grupą poddaną AAD, stwierdzono niższą wyjściową sumaryczną ocenę składowych zdrowia psychicznego (MCS, mental component summary) w grupie z ICD, przy czym w 12. miesiącu obserwacji ocena MCS nie różniła się istotnie w obu grupach. Sumaryczna ocena składowych zdrowia fizycznego (PCS, physical component summary) nie różniła się między grupami, co jest zgodne z wynikami innych badań obserwacyjnych i metaanaliz $[18,26]$.

W badaniu AVID wykazano negatywny wpływ interwencji wysokoenergetycznych na QoL. Podkreślono, że w grupie z ICD interwencja wysokoenergetyczna była niezależnym czynnikiem związanym z istotnym obniżeniem oceny zarówno w odniesieniu do zdrowia psychicznego (MCS), jak i fizycznego (PCS), jakkolwiek stopień redukcji QoL nie zależał od liczby interwencji wysokoenergetycznych [23].

Późniejsza retrospektywna analiza Steinberga i wsp. [10] oparta na populacji chorych z badania AVID wykazała, że śmiertelność okazała się istotnie wyższa u osób z niską wyjściową oceną QoL. Jakość życia była predyktorem poważnych zdarzeń sercowo-naczyniowych oraz śmiertelności.

\section{Badanie CABG-Patch}

Głównym założeniem badania CABG-Patch było porównanie implantacji ICD z leczeniem farmakologicznym u osób z chorobą niedokrwienną serca i upośledzoną funkcją skurczową lewej komory (frakcja wyrzutowa [EF, ejection fraction] < 35\%) oraz obecnością późnych potencjałów komorowych, poddawanych zabiegowi chirurgicznej rewaskularyzacji mięśnia sercowego (900 pacjentów; 446 z ICD i 454 bez ICD). Urządzenia ICD implantowano w trakcie zabiegu kardiochirugicznego. Nie wykazano istotnych korzyści w postaci zmniejszenia śmiertelności całkowitej u chorych z wszczepionym ICD [27].

Analiza QoL była celem substudy tego badania (490 pacjentów 228 z ICD i 262 bez ICD) [21]. Jakość życia, za pomocą SF-36, oceniano 6 miesięcy po zabiegu pomostowania aortalno-wieńcowego (CABG, coronary artery by-pass grafting). Wykazano niższą ocenę QoL w grupie chorych z ICD w porównaniu z grupą chorych bez ICD, przy czym różnica była bardziej wyrażona, jeśli pacjent doświadczył wysokoenergetycznej interwencji kardiowertera.

\section{Badanie CIDS}

Głównym celem badania CIDS było porównanie skuteczności leczenia antyarytmicznego amiodaronem i terapii z zastosowaniem ICD w profilaktyce wtórnej SCD (659 pacjentów; 328 z ICD i 331 leczonych amiodaronem). Dowiedziono zmniejszenia śmiertelności całkowitej w grupie z ICD, nie osiągnęła ona jednak poziomu istotności statystycznej [4]. W badaniu tym QoL oceniano wyjściowo oraz po 6 i 12 miesiącach obserwacji u 317 pacjentów. Wykazano poprawę QoL w czasie rocznej obserwacji w całej grupie chorych z ICD, przy czym nie dotyczyła pacjentów, którzy doświadczyli ponad 5 interwencji wysokoenergetycznych kardiowertera. Nie stwierdzono poprawy QoL w grupie leczonej amiodaronem [22].

\section{Badanie Pain-FREE RxII}

Obecnie wiadomo, że interwencje wysokoenergetyczne ICD wiążą się ze wzrostem ryzyka zgonu. Analizy danych z badań MADIT II [28], MADIT-CRT (Multicenter Automatic Defibrillator Implantation Trial - Cardiac Resynchronization Therapy) [29] oraz SCD-HeFT (Sudden Cardiac Death in Heart Failure Trial) [30] wykazały, że adekwatne interwencje wysokoenergetyczne kardiowertera wiązały się z odpowiednio 3,3-, 2,28- i 5,68-krotnym, a nieadekwatne interwencje - z odpowiednio 2,29-, 1,28- i 1,98-krotnym wzrostem śmiertelności całkowitej. Nie zaobserwowano natomiast (subanaliza MADIT II oraz MADIT-CRT) wzrostu ryzyka zgonu związanego z adekwatną ATP. Skłoniło to badaczy do poszukiwania rozwiązań redukujących liczbę interwencji wysokoenergetycznych ICD oraz do oceny bezpieczeństwa takiego postępowania. 
Tabela 1. Przegląd wybranych badań randomizowanych i obserwacyjnych, dotyczących jakości życia z implantowanym kardiowerterem-defibrylatorem (ICD, implantable cardioverter-defibrillator)

\begin{tabular}{|c|c|c|c|c|c|}
\hline Badanie, rok & $\begin{array}{l}\text { Liczba pacjentów } \\
\text { w badaniu }\end{array}$ & $\begin{array}{l}\text { Liczba pacjen- } \\
\text { tów objętych } \\
\text { analizą QoL }\end{array}$ & Profilaktyka SCD & $\begin{array}{l}\text { QoL chorych z ICD } \\
\text { w porównaniu } \\
\text { z grupą bez ICD }\end{array}$ & $\begin{array}{l}\text { Wpływ interwencji wysoko- } \\
\text { energetycznych ICD na QoL }\end{array}$ \\
\hline $\begin{array}{l}\text { CABG-Patch, } \\
1997\end{array}$ & $\begin{array}{c}900 \\
(446 \text { z ICD, } \\
454 \text { bez ICD) }\end{array}$ & 490 & Pierwotna & Niższa & Negatywny \\
\hline AVID, 1997 & $\begin{array}{c}1016 \\
(507 \text { z ICD, } \\
509 \text { z AAD) }\end{array}$ & 800 & Wtórna & $\begin{array}{l}\text { Niższa wyjściowo, } \\
\text { bez różnicy po } \\
12 \text { miesiącach }\end{array}$ & Negatywny \\
\hline CIDS, 2000 & $\begin{array}{c}659 \\
(328 \text { z ICD, } \\
331 \text { z AAD) }\end{array}$ & 317 & Wtórna & Wyższa & $\begin{array}{l}\text { Negatywny jeśli } \\
\geq 5 \text { interwencji }\end{array}$ \\
\hline $\begin{array}{l}\text { AMIOVIRT, } \\
2003\end{array}$ & $\begin{array}{c}103 \\
(51 \text { z ICD, } \\
52 \text { leczonych AAD) }\end{array}$ & 103 & Pierwotna & Bez różnicy & Bez wpływu \\
\hline $\begin{array}{l}\text { Pain-FREE, } \\
2004\end{array}$ & 634 z ICD & 98 z FVT & $\begin{array}{l}\text { Pierwotna } \\
\text { i wtórna }\end{array}$ & - & Negatywny \\
\hline
\end{tabular}

CABG-Patch - Coronary Artery Bypass Graft Patch Trial; AVID - The Antiarrhythmics versus Implantable Defibrillators; CIDS - Canadian Implantable Defibrillator Study; AMIOVIRT - Amiodarone versuS Implantable Defibrillator; Pain-FREE Rx II - Pacing Fast Ventricular Tachycardia Reduces Shock Therapies; AAD (antiarrhythmic drugs) - leki antyarytmiczne; FVT (fast ventricular tachycardia) - szybkie częstoskurcze komorowe

W opublikowanym w 2004 roku badaniu Pain-FREE Rxll (634 pacjentów) udowodniono skuteczność oraz bezpieczeństwo zastosowania ATP jako pierwszej terapii w przypadku szybkich częstoskurczów komorowych (FVT, fast ventricular tachycardia) w porównaniu z "tradycyjną" strategią terapii wysokoenergetycznej jako pierwszej opcji terapeutycznej [25]. Dodatkową analize tego badania, poświęconą ocenie QoL za pomocą kwestionariusza SF-36, przeprowadzono w podgrupie 98 pacjentów, którzy doświadczyli interwencji ICD z powodu FVT ( 43 pacjentów była to ATP bez interwencji wysokoenergetycznych, a u 55 pacjentów - interwencje wysokoenergetyczne). W 12. miesiącu od randomizacji wykazano istotną poprawę w zakresie 2 z 8 wskaźników QoL, natomiast w zakresie sumarycznej oceny zdrowia psychicznego - jedynie w grupie poddanej ATP. Późniejsza analiza Sweeney i wsp. [31], oparta na populacji chorych z badania Pain-FREE Rx II, jako jedna z nielicznych dotyczyła oceny różnic QoL między grupami pacjentów z ICD implantowanym w ramach pierwotnej oraz wtórnej profilaktyki SCD. Na podstawie retrospektywnej analizy autorzy nie wykazali różnic pod względem jakości życia między grupami chorych. Stwierdzono natomiast częstsze występowanie adekwatnych interwencji kardiowertera w grupie osób z ICD implantowanym w ramach profilaktyki wtórnej [31].

\section{Badanie AMIOVIRT}

Głównym celem badania AMIOVIRT było porównanie skuteczności terapii ICD z leczeniem antyarytmicznym amiodaronem. Badanie objęło 103 pacjentów z kardiomiopatią rozstrzeniową z bezobjawowymi nieutrwalonymi częstoskur- czami komorowymi. Drugorzędowym celem badania była ocena QoL. Nie wykazano istotnej statystycznej różnicy ani w zakresie śmiertelności całkowitej, ani QoL między badanymi grupami. Ponadto nie stwierdzono istotnego wpływu interwencji wysokoenergetycznej ICD na QoL [24].

\section{Podsumowanie wyników badań}

W tabeli 1 przedstawiono wpływ ICD na QoL na podstawie omówionych badań randomizowanych. W literaturze podkreśla się związek interwencji wysokoenergetycznych urządzenia z występowaniem zaburzeń lękowych i depresyjnych. Szacuje się, że takie zaburzenia występują u 24-38\% pacjentów w pierwszym roku po implantacji ICD [16] oraz że mogą one istotnie obniżać ocenę QoL $[32,33]$.

Lüderitz i wsp. [34] już w 1993 roku wykazali w grupie 57 pacjentów z ICD, że poziom lęku oceniany za pomocą State Trait Anxiety Inventory (STAI) był istotnie wyższy w grupie chorych, którzy doświadczyli więcej niż 5 interwencji wysokoenergetycznych. Z kolein w badaniu Johansen i wsp. [20] interwencje wysokoenergetyczne u 610 pacjentów wiązały się zarówno z istotnym obniżeniem QoL, jak i wzrostem poziomu zaburzeń lękowych i depresyjnych. Natomiast w pracy Kamphuis i wsp. [35] w grupie 167 pacjentów z ICD istotne klinicznie objawy lęku (oceniane za pomoca skali STAI) i depresji (ocenianie za pomocą Center for Epidemiologic Studies Depression Scale [CES-D]) wystąpiły u odpowiednio 31-83\% oraz 22-66\% chorych w czasie rocznej obserwacji. Ponadto stwierdzono, że interwencje wysokoenergetyczne ICD wiązały się z nasileniem zaburzeń lękowych i depresyjnych oraz z obniżeniem QoL [35]. Osoby, które doświadczyły interwencji wysokoenergetycznych, 
obawiają się kolejnej interwencji ICD - żyją w przeświadczeniu zagrożenia życia. W skrajnej postaci wielokrotne interwencje ICD mogą prowadzić do zespołu stresu pourazowego (PTSD, post-traumatic stress disorder) [36].

Pedersen i wsp. [37] dowiedli u 182 pacjentów, że wyrażany przez chorego wysoki poziom obaw związanych z ICD był niezależnym (silniejszym niż interwencje ICD) czynnikiem ryzyka wystąpienia zaburzeń lękowych i depresyjnych. Do interesujących wniosków doszli również autorzy wieloośrodkowego, prospektywnego badania TOVA (Triggers of Ventricular Arrythmias), które objęło 645 chorych z ICD. Wskazują one, że zaburzenia depresyjne w stopniach umiarkowanym i ciężkim były niezależnym czynnikiem ryzyka wystąpienia adekwatnych interwencji wysokoenergetycznych ICD [38]. Dwukierunkowy związek między interwencjami wysokoenergetycznymi a zaburzeniami depresyjnymi może doprowadzić do powstania „arytmicznego błędnego koła" [39] i wzrostu śmiertelności w tej grupie pacjentów.

Niektórzy autorzy zwracają uwagę, że za obniżenie QoL w większym stopniu niż interwencje wysokoenergetyczne odpowiadają dodatkowe choroby obciążające pacjentów z ICD [40]. Pedersen i wsp. [41] w grupie 154 chorych wykazali, że za obniżenie QoL u osób z ICD w większym stopniu niż interwencje wysokoenergetyczne odpowiada osobowość typu D, czyli osobowość charakteryzująca się skłonnością do przeżywania silnych i negatywnych emocji oraz do hamowania ich ekspresji.

\section{Dynamika zmian QoL po implantacji ICD}

Długoterminowe zachowanie się QoL chorych z ICD oceniali Carroll i wsp. [42] w 4-letniej obserwacji 41 chorych. W kolejnych latach badania chorzy istotnie lepiej oceniali swoje zdrowie psychiczne, mniejszy był poziom negatywnych emocji, pogorszeniu uległa jednak ocena zdrowia fizycznego [39].

Kochańska w grupie 80 chorych z ICD odnotowała najniższą ocenę jakości życia pomiędzy pierwszym a drugim rokiem od implantacji kardiowertera. Ocena jakości życia była najwyższa powyżej 5 roku od implantacji ICD [43].

\section{Ocena pacjentów z ICD zależnie od płci}

Dane dotyczące różnic płci w kontekście jakości życia oraz występowania zaburzeń lękowych i depresyjnych w populacji pacjentów z ICD są skąpe i niejednoznaczne. W literaturze podkreśla się, że kobiety w porównaniu do mężczyzn rzadziej biorą udział w badaniach klinicznych dotyczących ICD [44] oraz że wśród kobiet notuje się mniejszą ilość implantowanych kardiowerterów zarówno w profilaktyce pierwotnej, jak i wtórnej [45].

Habibović i wsp. [46] oceniali w oparciu o kwestionariusz SF-36 wpływ płci na poziom zaburzeń lękowych i jakość życia u 710 pacjentów, w tym - 81\% mężczyzn. Kobiety gorzej oceniały QoL w zakresie funkcjonowania fizycznego i witalności. Nie stwierdzono istotnych różnic w poziomie zaburzeń lękowych pomiędzy kobietami a mężczyznami. Natomiast w badaniu Spindler i wsp. [47] w grupie 535 pacjentów, w tym - 81,9\% mężczyzn, wykazano częstsze występowanie zaburzeń lękowych wśród kobiet. Kobiety prezentowały więcej obaw dotyczących ICD, gorzej oceniały jakość życia w zakresie 3 z 8 wskaźników jakości życia kwestionariusza SF-36 (funkcjonowanie fizyczne, funkcjonowania społeczne i zdrowie psychiczne). Nie odnotowano różnic płci w zakresie występowania zaburzeń depresyjnych [47]. W obserwacji Starrenburg i wsp. [48] QoL w 12 miesiącu po implantacji ICD była lepsza wśród kobiet w zakresie oceny funkcjonowania fizycznego jakkolwiek wykazano u kobiet wyższy poziom lęku.

\section{Wpływ ICD na QoL młodych pacjentów}

Szacuje się, że wśród populacji pacjentów z ICD chorzy młodzi - poniżej 50. roku życia stanowią około 10\% [49]. Młody wiek należy do czynników ryzyka obniżonej jakości życia pacjentów z ICD [50].

Pacjenci poniżej 50. roku życia w porównaniu ze starszymi chorymi wykazują wyższy poziom lęku [34], gorzej oceniają swoją QoL oraz podobnie jak chorzy, którzy doświadczyli interwencji wysokoenergetycznych ICD wyrażają więcej obaw takich jak strach przed wysiłkiem fizycznym, co może prowadzić do ograniczania aktywności życiowej w obawie przed sprowokowaniem kolejnej interwencji ICD [51].

W badaniu Wójcickiej i wsp. [52] lęk przed interwencją ICD deklarowało 84\% z badanych 45 młodych pacjentów w wieku 14-29 lat. Spośród osób, które doświadczyły interwencji wysokoenergetycznej ponad połowa ograniczyła swoją aktywność fizyczną, co może zaburzać prawidłowy rozwój psychofizyczny. Z kolei Koopman i wsp. [53], porównując QoL 25 pacjentów pediatrycznych z ICD z populacją ogólną chorych z ICD, wykazali częstsze występowanie zaburzeń lękowych i depresyjnych w grupie pediatrycznej, dodatkowo pogłębiane przez wystąpienie interwencji wysokoenergetycznej ICD.

Aktualne rekomendacje ESC nie zezwalają pacjentom z ICD na uprawianie sportu wyczynowego i amatorskiego o dużej intensywności. Zalecany jest wysiłek fizyczny o niewielkim lub umiarkowanym natężeniu [54]. Podkreśla się konieczność indywidualizowania natężenia wysiłku fizycznego podejmowanego najlepiej po 6 tygodniach od implantacji ICD i poprzedzonego elektrokardiograficznym testem wysiłkowym [55]. Istnieje bowiem zagrożenie wyzwolenia arytmii przez wysiłek fizyczny lub nieprawidłowej detekcji (odczytu) sygnału pobudzeń serca przez ICD w trakcie wysiłku, co może prowadzić do nieadekwatnych interwencji kardiowertera. 


\section{Prowadzenie pojazdów mechanicznych a terapia ICD}

Dla wielu pacjentów z ICD istotnym problemem są ograniczenia związane z prowadzeniem pojazdów mechanicznych mogące negatywnie wpływać na jakość życia chorych [56]. Szacuje się, że po implantacji ICD 9,1\% pacjentów przestaje prowadzić pojazdy [57]. Pacjenci obawiają się interwencji ICD w trakcie prowadzenia pojazdów i przestają czuć się pewnie za kierownicą. Obecne zalecenia Europejskiego Towarzystwa Kardiologicznego (ESC) dotyczące prowadzenia pojazdów zakazują zawodowego prowadzenia pojazdów osobom z ICD [58]. Zalecenia ESC dotyczące prowadzenia pojazdów mechanicznych dla kierowców niezawodowych przedstawiono w tabeli 2.

\section{Zaburzenia związane ze sferą seksualną wśród chorych z ICD}

Zaburzenia sfery seksualnej u pacjentów z ICD mogą wynikać z choroby podstawowej, działań niepożądanych farmakoterapii, ale także z problemów ściśle powiązanych z samym urządzeniem. Chorzy z ICD wyrażają liczne obawy związane z interwencją ICD podczas kontaktów seksualnych, narażeniem partnera na działanie kardiowertera czy, generalnie, brakiem informacji na temat życia seksualnego i ICD [59]. W badaniu Wójcickiej i wsp. [52] wśród osób pełnoletnich $41 \%$ kobiet przyznało się do poczucia strachu przed kontaktami seksualnymi. Takich obaw nie podzielał żaden mężczyzna. Według Dubina i wsp. [60] połowa młodych chorych poniżej 40. roku życia deklarowała problemy związane z kontaktami seksualnymi, a 44\% unikało takich kontaktów.

\section{Nowoczesne formy zdalnego kontrolowania ICD a jakość życia}

Zgodnie z obecnymi standardami opieki nad chorymi z ICD wymagane są okresowe wizyty kontrolne co 3-6 miesięcy w celu sprawdzenia funkcjonowania urządzenia i analizy zdarzeń arytmicznych zapisanych w pamięci kardiowertera. Postęp technologiczny umożliwia obecnie zdalną kontrolę ICD (remote control) za pośrednictwem sieci internetowej lub telefonicznej, bez konieczności osobistego zgłaszania się pacjenta do poradni. Dane z badań wskazują na wysoki i długotrwały poziom akceptacji pacjentów dla tego typu opieki [61], natomiast wpływ zdalnej kontroli ICD na ich QoL pozostaje niejednoznaczny, a dane są ograniczone. Ocena QoL stanowiła drugorzędowy cel wielu badań randomizowanych, których głównym celem była ocena bezpieczeństwa pacjentów i analiza aspektów ekonomicznych tej nowoczesnej metody opieki nad chorymi.

Wyniki z badania REFORM dotyczącego 155 pacjentów w 27. miesiącu obserwacji wykazały poprawę QoL w sto-
Tabela 2. Zalecenia Europejskiego Towarzystwa Kardiologicznego, dotyczące prowadzenia pojazdów mechanicznych przez pacjentów z implantowanym kardiowerterem-defibrylatorem (ICD, implantable cardioverter-defibrillator)

\begin{tabular}{lc}
\hline Implantacja ICD & $\begin{array}{c}\text { Zalecana karencja w prowadze- } \\
\text { niu pojazdów mechanicznych } \\
\text { (czas od zabiegu lub wystąpie- } \\
\text { nia arytmii) }\end{array}$ \\
\hline $\begin{array}{l}\text { Prewencja pierwotna } \\
\text { Odmowa przez pacjenta } \\
\text { implantacji ICD w prewencji } \\
\text { pierwotnej SCD }\end{array}$ & $\begin{array}{c}4 \text { tygodnie } \\
\text { Brak ograniczeń }\end{array}$ \\
$\begin{array}{l}\text { Prewencja wtórna } \\
\text { Odmowa przez pacjenta } \\
\text { implantacji ICD w prewencji } \\
\text { wtórnej SCD }\end{array}$ & 3 miesiące \\
Wymiana ICD & 7 miesięcy \\
Wymiana elektrody ICD & 1 tydzień \\
Interwencja ICD & 4 tygodnie \\
\hline $\begin{array}{l}\text { Adekwatna } \\
\text { Nieadekwatna }\end{array}$ & 3 miesiące \\
scD (sudden cardiac death) - nagła śmierć sercowa & Do czasu usunięcia przyczyny
\end{tabular}

sunku do jego wyjściowej oceny tylko w grupie pacjentów ze zdalnie kontrolowanymi ICD (oraz planowymi wizytami w poradni kardiologicznej raz w roku). W tym czasie QoL chorych objętych rutynowym schematem opieki kardiologicznej (planowe wizyty w poradni raz na 3 miesiące) pogorszyła się [62]. Natomiast Al-Khatib i wsp. [63] (151 pacjentów) wykazali niższą ocenę QoL w 6. miesiącu obserwacji wśród chorych ze zdalnie kontrolowanymi ICD niż w grupie chorych niepoddanych takiej kontroli, którzy odbywali planowe wizyty w poradni co 3 miesiące. Różnice te zacierały się w 12. miesiącu obserwacji [63]. Z kolei wyniki badania EuroEco u 312 pacjentów nie dowiodły istotnego wpływu na QoL dwóch opisanych wyżej strategii opieki nad chorymi z ICD w czasie 2-letniej obserwacji (zdalna kontrola ICD v. rutynowa opieka) [64].

\section{Implikacje kliniczne}

Zapobieganie obniżeniu QoL pacjentów z ICD stało się problemem wielodyscyplinarnym oraz współczesnym wyzwaniem dla osób opiekujących się tą dynamicznie rosnącą populacją. Edukacja chorych, informowanie o ograniczeniach i zdarzeniach niepożądanych związanych z terapią ICD mogą zmniejszyć poziom ich obaw oraz poprawić świadomość choroby.

W świetle danych dotyczących wpływu interwencji ICD na QoL kluczowe wydaje się obniżenie ryzyka wystąpienia adekwatnych i nieadekwatnych interwencji urządzenia 
poprzez leczenie choroby podstawowej oraz indywidualizacje programowania ICD. Również metody niefarmakologiczne, takie jak kontrolowany wysiłek fizyczny, mogą się okazać korzystne w prewencji obniżenia QoL w tej grupie pacjentów, a często występujące u chorych z ICD zaburzenia depresyjne i lękowe powinny się stać celem interwencji psychiatrycznych i psychologicznych $[39,65,66]$.

\section{Konflikt interesów}

Autorzy deklarują brak konfliktu interesów.

\section{Abstract}

Implantation of cardioverter-defibrillator (ICD) to reduce mortality in patients at high risk of life threatening ventricular arrhythmias has become treatment of choice. Population of patients with ICD has been dynamically increasing. Recently there has been growing interest in quality of life $(\mathrm{Q} o \mathrm{~L})$ in this group of patients. Results of studies remain controversial. The aim of this paper is to provide a systematic review of studies dedicated to the influence of therapy with the use of ICD on QoL.

Key words: ICD, quality of life, shocks

Folia Cardiologica 2016; 11, 1: 28-36

\section{Piśmiennictwo}

1. Świątecka G. Historia elektrostymulacji w Polsce. Folia Cardiol. Excerpta 2013; 8 (supl. C): 1-5.

2. Świątecka G., Lubiński A., Wilczek R. i wsp. Wszczepialny kardiowerter-defibrylator serca z elektrodą przezżylną. Doświadczenia własne. Cardiol. J. 1996; 2: 164-169.

3. The Antiarrhythmics versus Implantable Defibrillators (AVID) Investigators. A comparison of antiarrhythmic-drug therapy with implantable defibrillators in patients resuscitated from near-fatal ventricular arrhythmias. N. Engl. J Med. 1997; 337: 1576-1584.

4. Connolly S.J., Gent M., Roberts R.S. i wsp. Canadian implantable defibrillator study (CIDS): a randomized trial of the implantable cardioverter-defibrillator against amiodarone. Circulation 2000; 101: 1297-1302.

5. Kuck K.H., Cappato R., Siebels J. i wsp. Randomized comparison of antiarrhythmic drug therapy with implantable defibrillators in patients resuscitated from cardiac arrest: the Cardiac Arrest Study Hamburg (CASH). Circulation 2000; 102: 748-754.

6. Moss A.J., Jackson Hall W., Cannom D.S. i wsp. Improved survival with an implanted defibrillator in patients with coronary disease at high risk for ventricular arrhythmia. N. Engl. J. Med. 1996; 335: 1933-1940.

7. Moss A.J., Zareba W., Hall W.J. i wsp. Prophylactic implantation of a defibrillator in patients with myocardial infarction and reduced ejection fraction. N. Engl. J. Med. 2002; 346: 877-883.

8. Bardy G.H., Lee K.L., Mark D.B. i wsp. Amiodarone or an implantable cardioverter-defibrillator for congestive heart failure. N. Engl. J. Med. 2005; 352: 225-237.

9. Wytyczne ACC/AHA/ECS; Wytyczne dotyczące postępowania u chorych z komorowymi zaburzeniami rytmu serca i zapobiegania nagłemu zgonowi sercowemu - wersja skrócona. Kardiol. Pol. 2006; 64: 1373-1415.
10. Steinberg J.S., Joshi S., Schron E.B. i wsp. Psychosocial status predicts mortality in patients with life-threatening ventricular arrhythmias. Heart Rythm 2008; 5: 361-365.

11. WHOQOL Group. The World Health Organization quality of life assessment (WHOQOL): Position paper from the world health organization. Soc. Sci. Med. 1995; 41: 1403-1409.

12. Szyguła-Jurkiewicz B., Kowalska M., Mościński M. Jakość życia jako element oceny stanu zdrowia i efektywności leczenia chorych ze schorzeniami układu sercowo-naczyniowego. Folia Cardiol. 2011; 6: 62-71.

13. de Walden-Gałuszko K. Jakość życia - rozważania ogólne. W: de Walden-Gałuszko K., Majkowicz M. (red.). Jakość życia w chorobie nowotworowej, Wydawnictwo Uniwersytetu Gdańskiego, Gdańsk 1994: 13-22.

14. Uchmanowicz l., Łoboz-Grudzień K. Jakość życia - definicje i narzędzia badawcze - przegląd literatury. Family Med. Prim. Care Rev. 2008; 10: 245-252.

15. Moss A.J., Greenberg H., Case R.B. i wsp. Long-term clinical course of patients after termination of ventricular tachyarrhythmia by an implanted defibrillator. Circulation 2004; 110: 3760-3765.

16. Sears S.F., Conti J.B. Understanding implantable cardioverter defibrillator shocks and storms: medical and psychosocial considerations for research and clinical care. Clin. Cardiol. 2003; 26: 107-111.

17. Sears S.F., Todaro J.F., Lewis T.S. i wsp. Examining the psychosocial impact of implantable cardioverter defibrillators: a literature review. Clin. Cardiol. 1999; 22: 481-489.

18. Burke J.L., Hallas C.N., Clark-Carter D. i wsp. The psychosocial impact of the implantable cardioverter-defibrillator: a meta-analytic review. Br. J. Health Psychol. 2003; 8: 165-178.

19. Herrmann C., von zur Muhen F., Schaumann A. i wsp. Standardized assessment of psychological well-being and quality-of-life in patients 
with implanted defibrillators. Pacing Clin. Electrophysiol. 1997; 20: 95-103.

20. Johansen J.B., Pedersen S.S., Spindler H. i wsp. Symptomatic heart failure is the most important clinical correlate of impaired quality of life, anxiety, and depression in implantable cardioverter-defibrillator patients: a single-centre, cross-sectional study in 610 patients. Europace 200; 10: 545-551.

21. Namerow P.B., Firth B.R., Heywood G.M. i wsp. Quality-of-life six months after $C A B G$ surgery in patients randomized to ICD versus no ICD therapy: findings from the CABG Patch Trial. Pacing Clin. Electrophysiol. 1999; 22: 1305-1313.

22. Irvine J., Dorian P., Baker B. i wsp. Quality of life in the Canadian Implantable Defibrillator Study (CIDS). Am. Heart J. 2002; 144: 282-289 .

23. Schron E.B., Exner D.V., Yao Q. i wsp. Quality of life in the antiarrhythmics versus implantable defibrillator trial: impact of therapy and influences of adverse symptoms and defibrillator shocks. Circulation 2002; 105: 589-594.

24. Strickberger S.A., Hummel J.D., Bartlett T.G. i wsp. Amiodarone versus implantable cardioverter-defibrillator: randomized trial in patients with nonischemic dilated cardiomyopathy and asymptomatic nonsustained ventricular tachycardia - AMIOVIRT. J. Am. Coll. Cardiol. 2003; 41: 1707-1712.

25. Wathen M.S., DeGroot P.J., Sweeney M.O. i wsp. Prospective randomized multicenter trial of empirical antitachycardia pacing versus shocks for spontaneous rapid ventricular tachycardia in patients with implantable cardioverter-defibrillators: Pacing Fast Ventricular Tachycardia Reduces Shock Therapies (PainFREE Rx II) trial results. Circulation 2004; 110: 2591-2596.

26. Herbst J.H., Goodman M., Feldstein S., Reilly J.M. Health-related quality-of-life assessment of patients with life-threatening ventricular arrhythmias. Pacing Clin. Electrophysiol. 1999; 22: 915-926.

27. Bigger J.T. Prophylactic use of implanted cardiac defibrillators in patients at high risk for ventricular arrhythmias after coronary-artery bypass graft surgery. N. Engl. J. Med. 1997; 337: 1569-1575.

28. Daubert J.P., Zareba W., Cannom D.S. i wsp. Inappropriate implantable cardioverter-defibrillator shocks in MADIT II: frequency, mechanisms, predictors, and survival impact. J. Am. Coll. Cardiol. 2008; 51: 1366-1368.

29. Sood N., Ruwald A.C., Solomon S. i wsp. Association between myocardial substrate, implantable cardioverter-defibrillator shocks and mortality in MADIT-CRT. Eur. Heart J. 2014; 35: 106-115.

30. Poole J.E., Johnson G.W., Hellkamp A.S. i wsp. Prognostic importance of defibrillator shocks in patients with heart failure. N. Engl. J. Med. 2008; 359: 1009-1017.

31. Sweeney M.O., Wathen M.S., Volosin K. i wsp. Appropriate and inappropriate ventricular therapies, quality of life, and mortality among primary and secondary prevention implantable cardioverter defibrillator patients: results from the Pacing Fast VT REduces Shock ThErapies (PainFREE Rx II) trial. Circulation 2005; 111: 2898-2905.

32. Jacq F., Foulldrin G., Savouré A. i wsp. A comparison of anxiety, depression and quality of life between device shock and nonshock groups in implantable cardioverter defibrillator recipients. Gen. Hosp. Psychiatry 2009; 31: 266-273.

33. Godemann F., Butter C., Lampe F. i wsp. Determinants of quality of life in patients with implantable cardioverter/defibrillator. Qual, Life Res. 2004; 13: 411-430.
34. Lüderitz B., Jung W., Deister A. i wsp. Patient acceptance of the implantable cardioverter defibrillator in ventricular tachyarrhythmias. Pacing Clin. Electrophysiol. 1993; 16: 1815-1821.

35. Kamphuis H.C., De Leeuw J.R., Derksen R. Implantable cardioverter defibrillator recipients: quality of life In recipients with and without ICD shocks delivery. Europace 2003; 5: 381-389.

36. Maryniak A., Szumowski L., Walczak F. i wsp. Zespół stresu pourazowego u pacjenta z licznymi wyładowaniami ICD. Rola ablacji. Kardiol. Pol. 2006; 64: 910-912.

37. Pedersen S.S., van Domburg R.T., Theuns D.A. i wsp. Concerns about the implantable cardioverter defibrillator: a determinant of anxiety and depressive symptoms independent of experienced shocks. Am. Heart J. 2005; 149: 664-669.

38. Whang W., Albert C.M., Sears S.F. Depression as a predictor for appropriate shocks among patients with implantable cardioverter-defibrillators: results from the Triggers of Ventricular Arrhythmias (TOVA) study. J. Am. Coll. Cardiol. 2005; 45: 1090-1095.

39. Pedersen S.S., Van Den Broek K.C., Sears S.F. Psychological intervention following implantation of an implantable defibrillator: a review and future recommendations. Pacing Clin. Electrophysiol. 2007; 30: 1546-1554.

40. Szmulik M. Częstość interwencji antyarytmicznych a jakość życia u pacjentów z wszczepialnym kardiowerterem-defibrylatorem (ICD). Kardiol. Pol. 2011; 69 (supl. II): S39.

41. Pedersen S.S., Theuns D.A. Muskens-Heemskerk A. i wsp. Type-D personality but not implantable cardioverter-defibrillator indication is associated with impaired health-related quality of life 3 months post-implantation. Europace 2007; 9: 675-680.

42. Caroll D.L., Hamilton G.A. Long-term effects of Implanted cardioverter-defibrillator on health status, quality of life, and psychological state. Am. J. Crit. Care 2008; 17: 222-230.

43. Kochańska A., Zarzycka B., Świątecka G. i wsp. Quality of life in patients with an implantable cardioverter-defibillator - the significance of clinical factors. Arch. Med. Sci. 2008; 4: 409-416.

44. Curtis A.B. Are women worldwide under-treated with regard to cardiac resynchronization and sudden death prevention? J. Interv. Card. Electrophysiol. 2006; 17: 169-175.

45. Curtis L.H., Al-Khatib S.M., Shea A.M. i wsp. Sex differences in the use of implantable cardioverter-defibrillators for primary and secondary prevention of sudden cardiac death. JAMA 2007; 298: $1517-1524$.

46. Habibović M., van de Borek K.C., Theuns D.A. Gender disparities in anxiety and quality of life in patient with an implantable cardioverter-defibrillator; Europace 2011; 13: 1723-1730.

47. Spindler H., Johansen J.B., Andersen K. i wsp. Gender differences in anxiety and concerns about the cardioverter defibrillator. Pacing Clin. Electrophysiol. 2009; 32: 614-621.

48. Starrenburg A., Pedersen S., van den Broek K. i wsp. Gender differences in psychological distress and quality of life in patients with an ICD 1-year postimplant. Pacing Clin. Electrophysiol. 2014; 37: 843-852.

49. Sears S.F., Burns J.L., Handberg E. i wsp. Young at heart: understanding the unique psychosocial adjustment of young implantable cardioverter defibrillator recipients. Pacing Clin. Electrophysiol. 2001; 24: 1113-1117.

50. Friedmann E., Thomas S.A., Inguito P. Quality of life and psychological status of patients with implantable cardioverter-defibrillators. J. Interv. Card. Electrophysiol. 2006; 17: 65-72. 
51. Sears S.F., Eads A., Marhefka S. i wsp. The U.S. national survey of ICD recipients: examining the global and specific aspects of quality of life. Eur. Heart J. 1999; 20: 232.

52. Wójcicka M., Lewandowski M., Smolis-Bąk E., Szwed H. Psychological and clinical problems in young adults with implantable cardioverter-defibrillators. Kardiol. Pol. 2008; 66: 1050-1058.

53. Koopman H.M., Vrijmoet-Wiersma C.M., Langius J.N. i wsp. Psychological functioning and disease-related quality of life in pediatric patients with an implantable cardioverter-defibrillator. Pediatr. Cardiol. 2012; 33: $569-575$.

54. Pelliccia A., Fagard R., Bjrrrnstad H.H. i wsp. Recommendations for competitive sports participation in athletes with cardiovascular disease A consensus document from the Study Group of Sports Cardiology of the Working Group of Cardiac Rehabilitation and Exercise Physiology and the Working Group of Myocardial and Pericardial Diseases of the European Society of Cardiology. Eur. Heart J. 2005; 26: 1422-1445.

55. Heidbuchel H., Carré F. Exercise and competitive sports in patients with an implantable cardioverter-defibrillator Eur. Heart J. 2014; 35: 3097-3102.

56. Jung W., Luderitz B. Quality of life and driving in recipients of the implantable cardioverter-defibrillator. Am. J. Cardiol. 1996; 78: 51-56.

57. Mylotte D., Sheahan R.G., Nolan P.G. i wsp. The implantable defibrillator and return to operation of vehicles study. Europace 2013; 15: 212-218.

58. Vijgen J., Botto G., Camm J. i wsp. Consensus statement of the European Heart Rhythm Association: updated recommendations for driving by patients with implantable cardioverter defibrillators. Eur. J. Cardiovasc. Nurs. 2010; 9: 3-14.
59. Steinke E.E., Gill-Hopple K., Valdez D., Wooster M. Sexual concerns and educational needs after an implantable cardioverter defibrillator. Heart Lung 2005; 34: 299-308.

60. Dubin A.M., Batsford W.P., Lewis R.J., Rosenfeld L.E. Quality of life in patients receiving implantable cardioverter defibrillators before age 40. Pacing Clin. Electrophysiol. 1996; 19: 1555-1559.

61. Ricci R.P., Morichelli L., Quarta L. i wsp Long-term patient acceptance of and satisfaction with implanted device remote monitoring. Europace 2010; 12: 674-679.

62. Hindricks G., Elsner C., Piorkowski C. i wsp. Quarterly vs. yearly clinical follow-up of remotely monitored recipients of prophylactic implantable cardioverter-defibrillators: results of the REFORM Trial. Eur. Heart J. 2014; 35: 98-105.

63. Al-Khatib S.M., Piccini J.P., Knight D. i wsp. Remote monitoring of implantable Ccrdioverter defibrillators versus quarterly device interrogations in clinic: results from a randomized pilot clinical trial. J. Cardiovasc. Electrophysiol. 2010; 21: 545-550.

64. Heidbuche H., Hindricks G., Broudhurts P. i wsp. EuroEco (European Health Economic Trial on Home Monitoring in ICD Patients): a provider perspective in five European countries on costs and net financial impact of follow-up with or without remote monitoring. Eur. Heart J. 2014; 10: 1093.

65. Vanhees L., Kornaat M., Defoor J. i wsp. Effect of exercise training in patients with an implantable cardioverter defibrillator. Eur. Heart J. 2004; 25: 1120-1126.

66. Bilge A.K., Ozben B., Demican S. i wsp. Depression and anxiety status of patients with implantable cardioverter-defibrillator and precipitating factors. Pacing Clin. Electrophysiol. 2006; 29: 619-626. 